Review

\title{
A Comprehensive Profile of Mature MicroRNA in the Pig
}

Xiliang Wang ${ }^{1,2}$, David K.C. Cooper ${ }^{3}$, Zhiming Cai ${ }^{1}$, Lisha Mou ${ }^{1 *}$

1. Shenzhen Xenotransplantation Medical Engineering Research and Development Center, Institute of Translational Medicine, Shenzhen Second People's Hospital, First Affiliated

Hospital of Shenzhen University, Shenzhen, Guangdong, 518035, China

2. Department of Biochemistry, Zhongshan School of Medicine, Sun Yat-Sen University,

Guangzhou, Guangdong, 510080, China

3. Xenotransplantation Program, Department of Surgery, University of Alabama at

Birmingham, Birmingham, AL, 35233, USA

* Corresponding author

Lisha Mou PhD

Shenzhen Second People's Hospital

NO.3002 Sungang Road

Futian district, Shenzhen, Guandong 518035, China

Tel: (086) 0755-83366388-3230

Fax: (086) 0755-83366388-3230

E-mail: lishamou@gmail.com 
Abstract

The pig is an important source of meat production and provides a valuable model for certain human diseases. MicroRNA (miRNA), which is non-coding RNA and regulates gene expression at the posttranscriptional level, plays a critical role in various biological processes. Studies on identification and function of mature miRNAs in multiple pig tissues are increasing, yet the literature is limited. Therefore, we reviewed current research to determine the miRNAs expressed in specific pig tissues that are involved in carcass values (including muscle and adipocytes), reproduction (including pituitary, testis, and ovary), and development of some solid organs (e.g., brain, lung, kidney, and liver). We also discuss the possible regulating mechanisms of miRNA. Finally, as pig organs are suitable candidates for xenotransplantation, biomarkers of their miRNA in xenotransplantation were evaluated.

\section{Keywords:}

microRNA; pig; biomarker; xenotransplantation 


\section{Introduction}

The pig is one of the most widespread livestock species in the world, providing meat production [1]. Although relatively expensive to breed and with a relatively long gestation period (about 114 days) [2], the pig is still an ideal animal model for biomedical research because of its close phylogenetic proximity and similarities with humans, such as organ size, anatomical features, physiology, and organ development, compared with the mouse [3]. The pig has been used as a model to study various issues, such as reproduction [4], and the neuronal system [5], and is employed as a source of organs and cells in xenotransplantation [6].

Despite its apparent importance, knowledge about the pig is still much less than has been accumulated for the mouse and rat, such as genome organization and gene expression regulation. The latest porcine genome reference (Sscrofa 11.1) was shared in the NCBI website (https://www.ncbi.nlm.nih.gov/genome/?term=pig) by the Swine Genome Sequencing Consortium (SGSC) in 2017.

When compared with the human, the pig's genome is of comparable size and contains a similar number of protein-coding genes [7]. One might think that the pig should also have a similar number of microRNAs (miRNAs). However, the number of porcine miRNAs available in public databases is still limited, with only 411 mature miRNAs in the miRBase (v21) compared to human $(2,588)$ and mouse $(1,982)$ [8], partly because only part of the porcine genome is available for study [9]. The common research strategy on miRNA may include three aims: (i) characterization of miRNAs (including identification of novel 
miRNAs), (ii) determination of target genes, and (iii) illumination of function of miRNAs and target genes. These strategies have been widely used to describe the miRNAome in various pig tissues, such as muscle [9-12], brain [13], fat [14], embryo [3], pituitary [15], intestine [16], ovary [17] and testes [4].

This review is focused on the possible functions and regulating mechanisms of miRNAs in pigs, aiming towards a better understanding of the miRNAome in various tissues. Because of many similarities in morphology and physiology between pig and human, we also evaluate biomarker values of pig miRNA in pig-to-human xenotransplantation.

\section{Origins and mechanisms of miRNAs}

The miRNAs, which are typical transcripts of RNA polymerase II, are small non-coding RNAs in animals and plants [18]. They are transcribed from genomic DNA as long hairpins (pri-miRNA) with an imperfectly paired stem of $\sim 33$ bp [19]. The pri-miRNA is excised by Drosha to generate a pre-miRNA species in the nucleus, which is the first processing step. In the second processing step, pre-miRNA is exported from the nucleus and processed by Dicer to form the mature miRNA/miRNA* duplex of $\sim 22 \mathrm{bp}$ length. The miRNA is then assembled into RISC (RNA-induced silencing complexes). Generally, only one strand of the duplex is stably associated with an RISC [20] (Fig 1). 


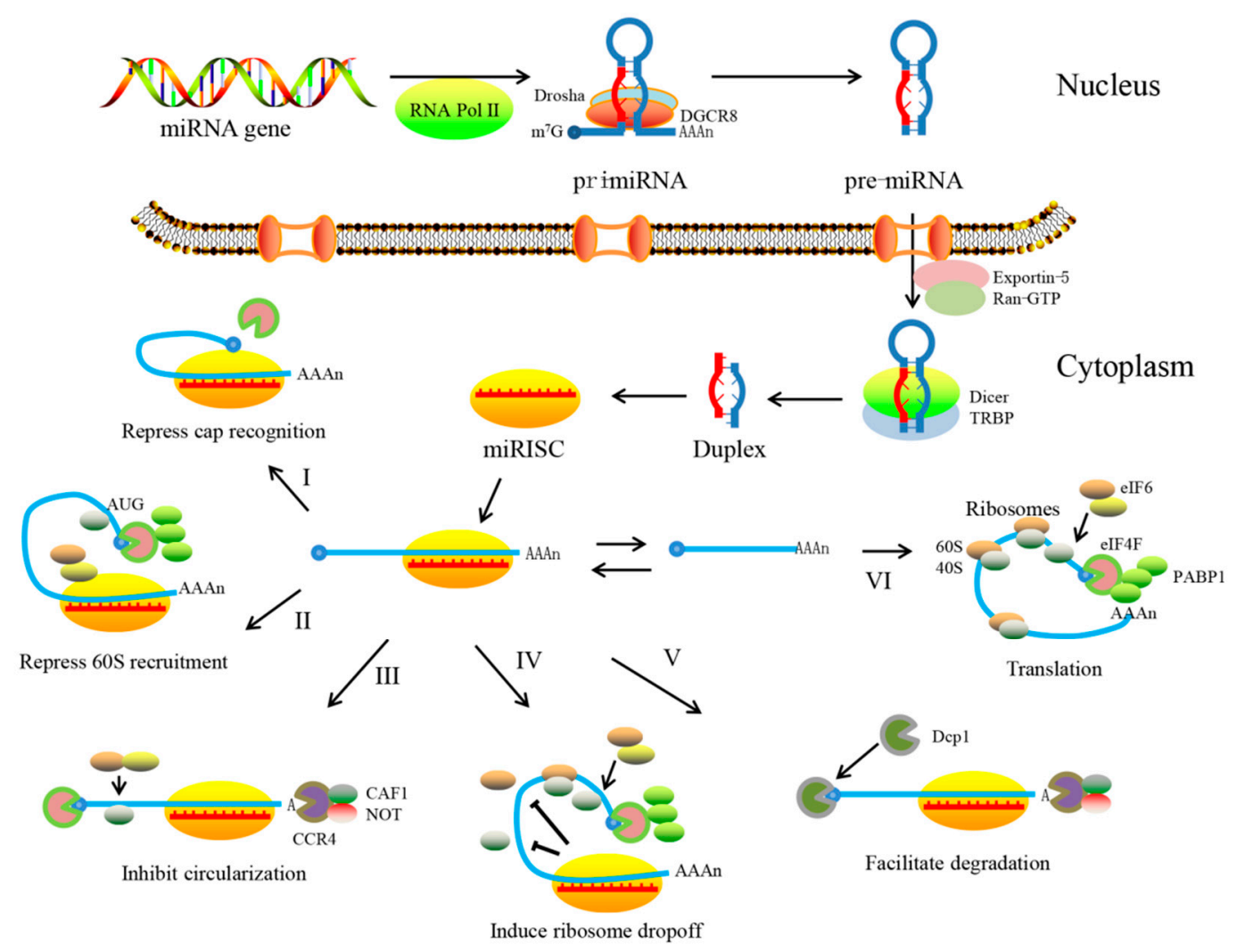

Figure 1. Biogenesis of miRNA and assembly into miRISC, and possible mechanisms of miRISC-mediated repression. In animals, the pri-miRNA is transcribed by RNA polymerase II from genomic DNA, and is processed by Drosha with the aid of DGCR8 to generate a pre-miRNA species, which is exported from the nucleus and processed by Dicer to form the mature miRNA/miRNA* duplex. Generally, only one strand of the duplex is then assembled into miRISC. When RISCs bind to mRNAs, they can repress initiation of translation at the stage of cap recognition (I) or 60S recruitment (II). Alternatively, they can induce mRNA deadenylation and thereby inhibit its circularization (III). They can also repress translation at the post-initiation stage through inducing ribosomes to dissociate prematurely (IV). They can also induce deadenylation followed by decapping to facilitate mRNA degradation (V). Without repression, mRNAs recruit initiation factors and ribosomal subunits and form circularized structures (VI). 
The miRNA acts as an adaptor for RISC to specifically recognize and regulate particular target mRNAs (Fig 1). Recognition involves Watson-Crick base pairing of the 2-8th miRNA nucleotides, which is the so-called seed region [21]. The binding sites of miRNA to mRNAs are located in the 3' UTR (un-translated region) and usually exist in multiple copies. Most animal miRNAs bind imperfectly with mismatches. When RISCs bind to mRNAs, they can repress initiation of translation at the stage of cap recognition or $60 \mathrm{~S}$ recruitment [22,23]. Alternatively, they can induce mRNA deadenylation and thereby inhibit its circularization [24]. They can also repress translation at post-initiation stage through inducing ribosomes to drop off prematurely [25]. They can also induce deadenylation followed by decapping to facilitate mRNA degradation [26,27] (Fig 1).

\section{miRNAs in pig skeletal muscle (Table 1)}

As the pig is an agriculturally important species, miRNAs that affect development and growth of economically important skeletal muscle are of interest. Several miRNAs may promote myogenesis [28-35] (Table 1). Several others have potential function during muscle development [35-51]. Others are involved in the development of the longissimus doris and psoas major muscles [46-51], whereas others [9,52-55] are expressed in a stage-specific manner across muscle development periods. Among them, the miR-1, miR-133, and miR-206, which are specifically expressed in cardiac and skeletal muscle [32], are frequently listed as the highest expressed miRNAs in porcine muscle $[9,10,41,56,57]$. These multiple above-mentioned miRNAs provide insights into the regulation of muscle growth, and are potential candidates for further improvement of meat quality and production using molecular approaches. 
Table 1: miRNAs in pig skeletal muscle

\begin{tabular}{|c|c|c|c|}
\hline miRNA & Target & Function & Reference \\
\hline miR-1a & HDAC4 & $\begin{array}{l}\text { promotes myogenesis during embryonic } \\
\text { development and muscle cell differentiation }\end{array}$ & $\begin{array}{l}28,29,46-4 \\
8\end{array}$ \\
\hline miR-133 & SRF & enhances the proliferation of myoblasts & $29,46-48$ \\
\hline $\operatorname{miR}-27 b$ & & $\begin{array}{l}\text { involved in myogenic differentiation, } \\
\text { fast-specific and glucocorticoid-dependent } \\
\text { myostatin expression }\end{array}$ & $30-32$ \\
\hline miR-148a & ROCK1 & $\begin{array}{l}\text { a novel myogenic miRNA that mediates } \\
\text { myogenic differentiation }\end{array}$ & 33 \\
\hline $\operatorname{miR}-143$ & & controls performance of different fiber types & 34,35 \\
\hline $\operatorname{miR}-378$ & $\begin{array}{l}\text { BMP2 } \\
\text { MAPK1 }\end{array}$ & a candidate for myogenesis & 36,37 \\
\hline $\operatorname{miR}-128$ & & $\begin{array}{l}\text { regulates adipogenesis, osteogenesis, and } \\
\text { myogenesis }\end{array}$ & 38 \\
\hline $\operatorname{miR}-126$ & & $\begin{array}{l}\text { attenuates insulin signaling and governs } \\
\text { vascular integrity and angiogenesis }\end{array}$ & 39,40 \\
\hline $\operatorname{miR}-92 \mathrm{a}$ & & regulates skeletal muscle growth & 35 \\
\hline $\begin{array}{l}\operatorname{miR}-127 \\
\operatorname{miR}-432 \\
\operatorname{miR}-136\end{array}$ & & $\begin{array}{l}\text { regulate the callipyge muscular hypertrophy } \\
\text { phenotype }\end{array}$ & 41,42 \\
\hline miR-10b & & $\begin{array}{l}\text { regulates myogenesis and muscle } \\
\text { development }\end{array}$ & 41,43 \\
\hline $\begin{array}{l}\text { let-7 } \\
\text { family }\end{array}$ & & key miRNA regulators of development & 44,45 \\
\hline $\begin{array}{l}\operatorname{miR}-103 \\
\operatorname{miR}-107\end{array}$ & & $\begin{array}{l}\text { involved in cellular Acetyl-CoA and lipid } \\
\text { levels }\end{array}$ & 46,49 \\
\hline $\operatorname{miR}-23$ & PGC-1 $1 \alpha$ & $\begin{array}{l}\text { affects the ratio of oxidative red muscle and } \\
\text { oxidative white muscle fibers }\end{array}$ & $46,50,51$ \\
\hline miR-181 & Hox-A11 & $\begin{array}{l}\text { barely detectable in resting muscle, } \\
\text { establishes the muscle phenotype }\end{array}$ & 52,53 \\
\hline miR-206 & $\mathrm{Cx} 43$ & $\begin{array}{l}\text { only highly-expressed in newly-formed } \\
\text { muscle fibers, promotes myoblast } \\
\text { differentiation and development }\end{array}$ & $32,54,55$ \\
\hline $\operatorname{miR}-486$ & & $\begin{array}{l}\text { Expressed postnatally, } \\
\text { acts as an inhibitor of myogenesis }\end{array}$ & 9 \\
\hline miR-376b & & $\begin{array}{l}\text { expressed prenatally, } \\
\text { plays a role in promotion of myogenesis }\end{array}$ & 9 \\
\hline $\begin{array}{l}\operatorname{miR}-363 \\
\operatorname{miR}-365 \\
\operatorname{miR}-422 b\end{array}$ & & $\begin{array}{l}\text { differentially expressed between } 33 \text { days } \\
\text { post-gestation and adult life, long-term } \\
\text { regulation of muscle growth and development }\end{array}$ & 9 \\
\hline
\end{tabular}


miRNAs in pig adipose tissue (Table 2)

In addition to skeletal muscle, adipose also affects the carcass value of a pig, including meat quality grade and yield. It also plays an important role in metabolic health. miR-143 was the first miRNA reported to be involved in adipose cell biology [58-60] (Table 2). The miR-210 [14,61] and the miR-27 family [14,62] are involved in adipogenesis. Several are abundant in both visceral and subcutaneous adipose tissues $[60,61,63,64]$, whereas others are subcutaneous adipose tissue-specific enriched miRNAs [64-67]. Some are specifically expressed in the greater omentum $[64,68,69]$. Research into pig adipose tissue miRNAs may be beneficial in meeting the increasing demand of consumers for improved pork quality, which is a topic of worldwide concern [14].

Table 2: miRNAs in pig adipose tissue

\begin{tabular}{|c|c|c|c|}
\hline miRNA & Target & Function & Reference \\
\hline miR-143 & ERK5 & promotes adipocyte differentiation & $58-60,63$ \\
\hline $\operatorname{miR}-210$ & & promotes adipogenesis & 14,61 \\
\hline miR-27 family & $\begin{array}{l}\text { INSR } \\
\text { IRS1-4 } \\
\text { PDK1/2 } \\
\text { CREB } \\
\text { S6K1 }\end{array}$ & inhibit adipogenesis & 14,62 \\
\hline $\operatorname{miR}-148 a-3 p$ & & involved in differentiation of 3T3-L1 pre-adipocytes & 61 \\
\hline $\begin{array}{l}\text { let-7a-1-5p } \\
\text { let-7f-5p }\end{array}$ & & play potential housekeeping roles in adipocytes & 64 \\
\hline $\operatorname{miR}-155-5 p$ & $\mathrm{C} / \mathrm{EBP}-\mathrm{b}$ & inhibits adipogenesis & $64-67$ \\
\hline $\begin{array}{l}\operatorname{miR}-193 b-3 p \\
\operatorname{miR}-365\end{array}$ & & $\begin{array}{l}\text { act as central regulators of brown fat differentiation } \\
\text { and adipogenesis }\end{array}$ & 64 \\
\hline $\operatorname{miR}-374 b-5 p$ & $\mathrm{C} / \mathrm{EBP}-\mathrm{b}$ & $\begin{array}{l}\text { involved in the effect of maternal dietary protein on } \\
\text { lipid metabolism }\end{array}$ & 64 \\
\hline $\begin{array}{l}\operatorname{miR}-18 a-3 p \\
\text { miR-20-3p } \\
\text { miR-19b-1-5p } \\
\text { miR-181a-2-3p } \\
\text { miR-181b-2-3p }\end{array}$ & & $\begin{array}{l}\text { involved in development and production of } \\
\text { pro-inflammatory B cells and T cells }\end{array}$ & $64,68,69$ \\
\hline
\end{tabular}


miRNAs in other pig tissues (Table 3)

Although most research has hitherto been dedicated to miRNA's roles in meat quality, emerging research has evaluated miRNA in other solid tissues in pigs, including, but not limited to, reproduction. Many miRNAs are enriched in reproductive tissues $[4,15,17,44]$ (Table 3). Others may play a role in differentiating neurons in brain development $[3,13,70-73]$. Several are highly-expressed in big solid organs $[1,44,74-76]$. The miR-200b and miR-214 are key miRNAs in tooth development $[77,78]$.

When a miRNA is predominant, this suggests that it could have a significant role in the tissue, and that it could govern or be implicated in the major constitutive functions carried out by this tissue.

Table 3: miRNAs in other pig tissues

\begin{tabular}{|c|c|c|c|}
\hline miRNA & Tissue & Function & Reference \\
\hline $\operatorname{miR}-7$ & pituitary & & 15 \\
\hline $\begin{array}{l}\text { miR-760 } \\
\text { miR-1296 } \\
\text { miR-137 } \\
\text { miR-362 }\end{array}$ & pituitary & & 44 \\
\hline $\begin{array}{l}\text { miR-153 } \\
\text { miR-205 }\end{array}$ & mature testis & & 4 \\
\hline $\begin{array}{l}\operatorname{miR}-196 \\
\operatorname{miR}-149 * \\
\operatorname{miR}-485-3 p\end{array}$ & $\begin{array}{l}\text { immature } \\
\text { testis }\end{array}$ & & 4 \\
\hline $\operatorname{miR}-21-5 p$ & ovary, testis & & 17 \\
\hline $\begin{array}{l}\text { miR-9 } \\
\text { miR-30a }\end{array}$ & head region & $\begin{array}{l}\text { miR-9 regulates proliferation and } \\
\text { migration of human neural } \\
\text { progenitor cells }\end{array}$ & 3,70 \\
\hline $\begin{array}{l}\text { miR-17 } \\
\text { miR-106a }\end{array}$ & $\begin{array}{l}\text { neurons and } \\
\text { brain }\end{array}$ & $\begin{array}{l}\text { involved in neurons } \\
\text { differentiation and brain } \\
\text { development by regulating APP }\end{array}$ & 13,71 \\
\hline miR-29c & adult cortex, & an effective biomarker of & 72,73 \\
\hline
\end{tabular}




\begin{tabular}{llll}
\hline & cerebellum & radiation-induced brain response & \\
miR-320 & lung & & 74 \\
miR-375 & $\begin{array}{l}\text { stomach and } \\
\text { lymph nodes }\end{array}$ & 74 \\
\hline $\begin{array}{l}\text { miR-23a } \\
\text { miR-125b }\end{array}$ & kidney & 1 \\
miR-23b & & & \\
miR-126 & & plays a role in cholesterol, fatty & $44,75,76$ \\
miR-200b-3p & & acid, and lipid metabolism & \\
miR-122-5p & liver & $\begin{array}{l}\text { miR-200b is key in tooth } \\
\text { development }\end{array}$ & 77,78 \\
\hline $\begin{array}{l}\text { miR-200b } \\
\text { miR-214 }\end{array}$ & teeth & & \\
\hline
\end{tabular}

\section{Biomarker values of miRNA in xenotransplantation}

The pig has become the most suitable candidate as a source organ for xenotransplantation to overcome the growing gap between the need and availability of human donor organs [6].

Detailed genome information and emerging gene-editing technologies increase the possibility of producing pigs specific for this purpose. The xenotransplantation of organs from gene-modified pigs is associated with longer survival and less rejection [6]. Biopsy is the gold standard for diagnosis of conditions such as acute rejection (AR), disease recurrence, and drug toxicity [79]. However, biopsy often relies on 'subjective' measures, with some variability in results and reporting methods among pathologists, or limited diagnostic accuracy associated with sampling error [80]. There is a critical need for biomarkers for early diagnosis, treatment response, and outcome prediction in organ transplantation, with the final goal of an individualized treatment to prevent or reverse graft injury [81]. 
The miRNAs may be ideal candidates as biomarkers of disease [82-86]. Several factors (the relatively consistent changes seen in diseases, reliable analysis methods, tissue-specific expression patterns, less complexity than mRNAs, no post-processing modification, and amplifiable signals) contribute to making miRNAs ideal candidates, especially in the cancer diagnostic field [87-91]. Profiling miRNAs can be used as markers of organ donor quality/ischemia reperfusion injury [92]. The strong association between miRNA expression and allograft function or acute rejection demonstrates that miRNAs may be excellent biomarkers of human allograft status [81,93]. For example, levels of miR-142-5p, miR-155 and miR-223 can each predict acute rejection with $>90 \%$ sensitivity and specificity in human renal allografts $[94,95]$. Because miRNAs are stably expressed in serum, plasma, urine, saliva, and other body fluids, this makes them ideal non-invasive biomarkers [83] to accurately monitor graft function in xenotransplantation. There are minor differences in the nucleotide composition of miRNAs among species [74]. Therefore, the circulating pig-specific miRNAs in human body fluids have vast potential to be biomarkers after pig-to-human xenotransplantation. Graft tissue and/or circulating miRNA profiles may be used as new biomarkers in guiding the diagnostic, therapeutic, and prognostic strategies that are associated with over-immunosuppression, organ toxicity, and graft rejection or loss.

\section{Discussion}

Knowledge of human development, physiology, and pathology can be obtained from suitable animal models, especially the mouse and rat, but many of their physiological parameters (e.g., size, respiratory rate) are significantly different from those in humans [2]. 
Rodent genomes also have a faster rate of evolution than the human genome [96]. The pig is not only of significant agricultural value, but is also considered a good model for biomedical research [97]. Furthermore, pigs have been identified as the most promising source of organs for xenotransplantation to counteract the shortage of human organs for transplantation [98].

Many miRNAs are highly-conserved among related species [99]. Studies on miRNAs in the pig will be beneficial in understanding their key regulatory roles in humans. To obtain a better insight into the biological functions of miRNAs, it is imperative to identify all miRNAs expressed in the pig genome and their potential mRNA targets $[100,101]$, which is becoming easier using bioinformatic methods, with a growing number of excellent tools becoming available $[8,102]$. However, the false discovery rate in predictive-results remains high, and experimental validation will be needed after bioinformatic prediction. We suggest, however, that pig miRNA profiles will be used as new biomarkers in pig-to-human xenotransplantation.

\section{Acknowledgments}

This work was supported by Science and Technology Planning Project of Guangdong Province, China (2016A020226025), Shenzhen Foundation of Science and Technology (JCYJ20160229204849975, and GCZX2015043017281705), Shenzhen Foundation of Science and Technology grant (SZXJ2017021), and Fund for High Level University's Medical Discipline Construction (2016031638). The costs to publish in open access is covered by Shenzhen Foundation of Science and Technology grant (SZXJ2017021). 


\title{
Author Contributions
}

X.L.W. wrote the manuscript, D.C. revised the manuscript, Z.M.C editing the manuscript,

L.S.M. directed the work.

\section{Conflict of interest}

The authors declare no conflict of interest.

\author{
Abbreviations \\ miRNA microRNA \\ RISC RNA-induced silencing complexes
}




\section{References}

1. Timoneda, O.; Balcells, I.; Nunez, J.I.; Egea, R.; Vera, G.; Castello, A.; Tomas, A.; Sanchez, A. Mirna expression profile analysis in kidney of different porcine breeds. PLoS One 2013, 8, e55402.

2. Martini, P.; Sales, G.; Brugiolo, M.; Gandaglia, A.; Naso, F.; De Pitta, C.; Spina, M.; Gerosa, G.; Chemello, F.; Romualdi, C., et al. Tissue-specific expression and regulatory networks of pig micrornaome. PLoS One 2014, 9, e89755.

3. Zhou, Y.; Tang, X.; Song, Q.; Ji, Y.; Wang, H.; Wang, H.; Jiao, H.; Ouyang, H.; Pang, D. Identification and characterization of pig embryo micrornas by solexa sequencing. Reproduction in Domestic Animals 2013, 48, 112-120.

4. Lian, C.; Sun, B.; Niu, S.; Yang, R.; Liu, B.; Lu, C.; Meng, J.; Qiu, Z.; Zhang, L.; Zhao, Z. A comparative profile of the microrna transcriptome in immature and mature porcine testes using solexa deep sequencing. The FEBS journal 2012, 279, 964-975.

5. Kragh, P.M.; Nielsen, A.L.; Li, J.; Du, Y.; Lin, L.; Schmidt, M.; Bogh, I.B.; Holm, I.E.; Jakobsen, J.E.; Johansen, M.G., et al. Hemizygous minipigs produced by random gene insertion and handmade cloning express the alzheimer's disease-causing dominant mutation appsw. Transgenic research 2009, 18, 545-558.

6. Cooper, D.K.C.; Ezzelarab, M.B.; Hara, H.; Iwase, H.; Lee, W.; Wijkstrom, M.; Bottino, R. The pathobiology of pig-to-primate xenotransplantation: A historical review. Xenotransplantation 2016, 23, 83-105.

7. Groenen, M.A.; Archibald, A.L.; Uenishi, H.; Tuggle, C.K.; Takeuchi, Y.; Rothschild, M.F.; Rogel-Gaillard, C.; Park, C.; Milan, D.; Megens, H.J., et al. Analyses of pig genomes provide insight into porcine demography and evolution. Nature 2012, 491, 393-398.

8. Kozomara, A.; Griffiths-Jones, S. Mirbase: Annotating high confidence micrornas using deep sequencing data. Nucleic Acids Res 2014, 42, D68-73.

9. Huang, T.H.; Zhu, M.J.; Li, X.Y.; Zhao, S.H. Discovery of porcine micrornas and profiling from skeletal muscle tissues during development. PLoS One 2008, 3, e3225.

10. McDaneld, T.G.; Smith, T.P.; Harhay, G.P.; Wiedmann, R.T. Next-generation sequencing of the porcine skeletal muscle transcriptome for computational prediction of microrna gene targets. PLoS One 2012, 7, e42039.

11. Xie, S.S.; Huang, T.H.; Shen, Y.; Li, X.Y.; Zhang, X.X.; Zhu, M.J.; Qin, H.Y.; Zhao, S.H. Identification and characterization of micrornas from porcine skeletal muscle. Animal genetics 2010, 41, 179-190.

12. Maxmen, A. Model pigs face messy path. Nature 2012, 486, 453.

13. Podolska, A.; Kaczkowski, B.; Kamp Busk, P.; Sokilde, R.; Litman, T.; Fredholm, M.; Cirera, S. Microrna expression profiling of the porcine developing brain. PLoS One 2011, 6, e14494.

14. Guo, Y.; Mo, D.; Zhang, Y.; Zhang, Y.; Cong, P.; Xiao, S.; He, Z.; Liu, X.; Chen, Y. Micrornaome comparison between intramuscular and subcutaneous vascular stem cell adipogenesis. Plos One 2012, 7, e45410.

15. Li, H.; Xi, Q.; Xiong, Y.; Cheng, X.; Qi, Q.; Yang, L.; Shu, G.; Wang, S.; Wang, L.; 
Gao, P., et al. A comprehensive expression profile of micrornas in porcine pituitary. Plos One 2011, 6, e24883.

16. Sharbati, S.; Friedlander, M.R.; Sharbati, J.; Hoeke, L.; Chen, W.; Keller, A.; Stahler, P.F.; Rajewsky, N.; Einspanier, R. Deciphering the porcine intestinal microrna transcriptome. BMC Genomics 2010, 11, 275.

17. Li, M.; Liu, Y.; Wang, T.; Guan, J.; Luo, Z.; Chen, H.; Wang, X.; Chen, L.; Ma, J.; $\mathrm{Mu}, \mathrm{Z}$., et al. Repertoire of porcine micrornas in adult ovary and testis by deep sequencing. International journal of biological sciences 2011, 7, 1045-1055.

18. Kim, V.N. Microrna biogenesis: Coordinated cropping and dicing. Nat Rev Mol Cell Biol 2005, 6, 376-385.

19. Bartel, D.P. Micrornas: Genomics, biogenesis, mechanism, and function. Cell 2004, 116, 281-297.

20. Kim, V.N.; Han, J.; Siomi, M.C. Biogenesis of small rnas in animals. Nat Rev Mol Cell Biol 2009, 10, 126-139.

21. Pillai, R.S.; Artus, C.G.; Filipowicz, W. Tethering of human ago proteins to mrna mimics the mirna-mediated repression of protein synthesis. RNA 2004, 10, 1518-1525.

22. Ding, X.C.; Großhans, H. Repression of c. Elegans microrna targets at the initiation level of translation requires gw182 proteins. EMBO J 2009, 28, 213-222.

23. Wakiyama, M.; Takimoto, K.; Ohara, O.; Yokoyama, S. Let-7 microrna-mediated mrna deadenylation and translational repression in a mammalian cell-free system. Genes \& development 2007, 21, 1857-1862.

24. Behm-Ansmant, I.; Rehwinkel, J.; Doerks, T.; Stark, A.; Bork, P.; Izaurralde, E. Mrna degradation by mirnas and gw182 requires both ccr4:Not deadenylase and dcp1:Dcp2 decapping complexes. Genes \& Development 2006, 20, 1885-1898.

25. Nottrott, S.; Simard, M.J.; Richter, J.D. Human let-7a mirna blocks protein production on actively translating polyribosomes. Nat Struct Mol Biol 2006, 13, 1108-1114.

26. Carthew, R.W.; Sontheimer, E.J. Origins and mechanisms of mirnas and sirnas. Cell 2009, 136, 642-655.

27. Giraldez, A.J.; Mishima, Y.; Rihel, J.; Grocock, R.J.; Van Dongen, S.; Inoue, K.; Enright, A.J.; Schier, A.F. Zebrafish mir-430 promotes deadenylation and clearance of maternal mrnas. Science 2006, 312, 75-79.

28. Liu, N.; Williams, A.H.; Kim, Y.; McAnally, J.; Bezprozvannaya, S.; Sutherland, L.B.; Richardson, J.A.; Bassel-Duby, R.; Olson, E.N. An intragenic mef2-dependent enhancer directs muscle-specific expression of micrornas 1 and 133. Proceedings of the National Academy of Sciences of the United States of America 2007, 104, 20844-20849.

29. Chen, J.F.; Mandel, E.M.; Thomson, J.M.; Wu, Q.; Callis, T.E.; Hammond, S.M.; Conlon, F.L.; Wang, D.Z. The role of microrna-1 and microrna-133 in skeletal muscle proliferation and differentiation. Nat Genet 2006, 38, 228-233.

30. Lozano-Velasco, E.; Contreras, A.; Crist, C.; Hernandez-Torres, F.; Franco, D.; Aranega, A.E. Pitx2c modulates pax3+/pax $7+$ cell populations and regulates pax 3 expression by repressing mir27 expression during myogenesis. Dev Biol 2011, 357, 165-178. 
31. Allen, D.L.; Loh, A.S. Posttranscriptional mechanisms involving microrna-27a and $\mathrm{b}$ contribute to fast-specific and glucocorticoid-mediated myostatin expression in skeletal muscle. American journal of physiology. Cell physiology 2011, 300, C124-C137.

32. Qin, L.; Chen, Y.; Liu, X.; Ye, S.; Yu, K.; Huang, Z.; Yu, J.; Zhou, X.; Chen, H.; Mo, D. Integrative analysis of porcine micrornaome during skeletal muscle development. PLoS One 2013, 8, e72418.

33. Zhang, J.; Ying, Z.Z.; Tang, Z.L.; Long, L.Q.; Li, K. Microrna-148a promotes myogenic differentiation by targeting the rock1 gene. J Biol Chem 2012, 287, 21093-21101.

34. Chen, L.; Wu, P.; Guo, X.H.; Hu, Y.; Li, Y.L.; Shi, J.; Wang, K.Z.; Chu, W.Y.; Zhang, J.S. Mir-143: A novel regulator of myod expression in fast and slow muscles of siniperca chuatsi. Current molecular medicine 2014, 14, 370-375.

35. Zuo, J.; Wu, F.; Liu, Y.; Xiao, J.; Xu, M.; Yu, Q.; Xia, M.; He, X.; Zou, S.; Tan, H., et al. Microrna transcriptome profile analysis in porcine muscle and the effect of mir-143 on the myh7 gene and protein. PLoS One 2015, 10, e0124873.

36. Gagan, J.; Dey, B.K.; Layer, R.; Yan, Z.; Dutta, A. Microrna-378 targets the myogenic repressor myor during myoblast differentiation. $J$ Biol Chem 2011, 286, 19431-19438.

37. Hou, X.; Tang, Z.; Liu, H.; Wang, N.; Ju, H.; Li, K. Discovery of micrornas associated with myogenesis by deep sequencing of serial developmental skeletal muscles in pigs. PLoS One 2012, 7, e52123.

38. Motohashi, N.; Alexander, M.S.; Casar, J.C.; Kunkel, L.M. Identification of a novel microrna that regulates the proliferation and differentiation in muscle side population cells. Stem Cells and Development 2012, 21, 3031-3043.

39. Ryu, H.S.; Park, S.Y.; Ma, D.; Zhang, J.; Lee, W. The induction of microrna targeting irs-1 is involved in the development of insulin resistance under conditions of mitochondrial dysfunction in hepatocytes. PLoS One 2011, 6, e17343.

40. Wang, S.; Aurora, A.B.; Johnson, B.A.; Qi, X.; McAnally, J.; Hill, J.A.; Richardson, J.A.; Bassel-Duby, R.; Olson, E.N. The endothelial-specific microrna mir-126 governs vascular integrity and angiogenesis. Developmental cell 2008, 15, 261-271.

41. Nielsen, M.; Hansen, J.H.; Hedegaard, J.; Nielsen, R.O.; Panitz, F.; Bendixen, C.; Thomsen, B. Microrna identity and abundance in porcine skeletal muscles determined by deep sequencing. Animal genetics 2010, 41, 159-168.

42. Davis, E.; Caiment, F.; Tordoir, X.; Cavaille, J.; Ferguson-Smith, A.; Cockett, N.; Georges, M.; Charlier, C. Rnai-mediated allelic trans-interaction at the imprinted rtl1/peg11 locus. Curr Biol 2005, 15, 743-749.

43. Li, T.; Wu, R.; Zhang, Y.; Zhu, D. A systematic analysis of the skeletal muscle mirna transcriptome of chicken varieties with divergent skeletal muscle growth identifies novel mirnas and differentially expressed mirnas. BMC Genomics 2011, 12, 186.

44. Li, M.; Xia, Y.; Gu, Y.; Zhang, K.; Lang, Q.; Chen, L.; Guan, J.; Luo, Z.; Chen, H.; Li, Y., et al. Micrornaome of porcine pre- and postnatal development. PLoS One 2010, 5, e11541.

45. Roush, S.; Slack, F.J. The let-7 family of micrornas. Trends in cell biology 2008, 18, 505-516. 
46. Liu, Y.; Li, M.; Ma, J.; Jie, Z.; Zhou, C.; Tao, W.; Gao, X.; Li, X. Identification of differences in microrna transcriptomes between porcine oxidative and glycolytic skeletal muscles. BMC Molecular Biology 2013, 14, 1-8.

47. Niu, Z.; Li, A.; Zhang, S.X.; Schwartz, R.J. Serum response factor micromanaging cardiogenesis. Current opinion in cell biology 2007, 19, 618-627.

48. Boutz, P.L.; Chawla, G.; Stoilov, P.; Black, D.L. Micrornas regulate the expression of the alternative splicing factor nptb during muscle development. Genes Dev 2007, 21,71-84.

49. Mahoney, D.J.; Parise, G.; Melov, S.; Safdar, A.; Tarnopolsky, M.A. Analysis of global mrna expression in human skeletal muscle during recovery from endurance exercise. FASEB journal : official publication of the Federation of American Societies for Experimental Biology 2005, 19, 1498-1500.

50. Handschin, C.; Spiegelman, B.M. The role of exercise and pgclalpha in inflammation and chronic disease. Nature 2008, 454, 463-469.

51. Safdar, A.; Abadi, A.; Akhtar, M.; Hettinga, B.P.; Tarnopolsky, M.A. Mirna in the regulation of skeletal muscle adaptation to acute endurance exercise in $\mathrm{c} 57 \mathrm{bl} / 6 \mathrm{j}$ male mice. PLoS One 2009, 4, e5610.

52. Naguibneva, I.; Ameyar-Zazoua, M.; Polesskaya, A.; Ait-Si-Ali, S.; Groisman, R.; Souidi, M.; Cuvellier, S.; Harel-Bellan, A. The microrna mir-181 targets the homeobox protein hox-a11 during mammalian myoblast differentiation. Nature cell biology 2006, 8, 278-284.

53. Townley-Tilson, W.H.; Callis, T.E.; Wang, D. Micrornas 1, 133, and 206: Critical factors of skeletal and cardiac muscle development, function, and disease. The international journal of biochemistry \& cell biology 2010, 42, 1252-1255.

54. Yuasa, K.; Hagiwara, Y.; Ando, M.; Nakamura, A.; Takeda, S.i.; Hijikata, T. Microrna-206 is highly expressed in newly formed muscle fibers: Implications regarding potential for muscle regeneration and maturation in muscular dystrophy. Cell Structure and Function 2008, 33, 163-169.

55. Anderson, C.; Catoe, H.; Werner, R. Mir-206 regulates connexin43 expression during skeletal muscle development. Nucleic Acids Res 2006, 34, 5863-5871.

56. McDaneld, T.G.; Smith, T.P.; Doumit, M.E.; Miles, J.R.; Coutinho, L.L.; Sonstegard, T.S.; Matukumalli, L.K.; Nonneman, D.J.; Wiedmann, R.T. Microrna transcriptome profiles during swine skeletal muscle development. BMC Genomics 2009, 10, 77.

57. Brennecke, J.; Stark, A.; Cohen, S.M. Not mir-ly muscular: Micrornas and muscle development. Genes \& Development 2005, 19, 2261-2264.

58. Esau, C.; Kang, X.; Peralta, E.; Hanson, E.; Marcusson, E.G.; Ravichandran, L.V.; Sun, Y.; Koo, S.; Perera, R.J.; Jain, R., et al. Microrna-143 regulates adipocyte differentiation. J Biol Chem 2004, 279, 52361-52365.

59. Cordes, K.R.; Sheehy, N.T.; White, M.P.; Berry, E.C.; Morton, S.U.; Muth, A.N.; Lee, T.H.; Miano, J.M.; Ivey, K.N.; Srivastava, D. Mir-145 and mir-143 regulate smooth muscle cell fate and plasticity. Nature 2009, 460, 705-710.

60. Li, G.; Li, Y.; Li, X.; Ning, X.; Li, M.; Yang, G. Microrna identity and abundance in developing swine adipose tissue as determined by solexa sequencing. Journal of cellular biochemistry 2011, 112, 1318-1328.

61. Qin, L.; Chen, Y.; Niu, Y.; Chen, W.; Wang, Q.; Xiao, S.; Li, A.; Xie, Y.; Li, J.; Zhao, 
X., et al. A deep investigation into the adipogenesis mechanism: Profile of micrornas regulating adipogenesis by modulating the canonical wnt $/ \beta$-catenin signaling pathway. BMC Genomics 2010, 11, 320-320.

62. Karbiener, M.; Fischer, C.; Nowitsch, S.; Opriessnig, P.; Papak, C.; Ailhaud, G.; Dani, C.; Amri, E.Z.; Scheideler, M. Microrna mir-27b impairs human adipocyte differentiation and targets ppargamma. Biochem Biophys Res Commun 2009, 390, 247-251.

63. Alexander, R.; Lodish, H.; Sun, L. Micrornas in adipogenesis and as therapeutic targets for obesity. Expert opinion on therapeutic targets 2011, 15, 623-636.

64. Ma, J.; Jiang, Z.; He, S.; Liu, Y.; Chen, L.; Long, K.; Jin, L.; Jiang, A.; Zhu, L.; Wang, J., et al. Intrinsic features in microrna transcriptomes link porcine visceral rather than subcutaneous adipose tissues to metabolic risk. PLoS One 2013, 8, e80041.

65. Liu, S.; Yang, Y.; Wu, J. Tnf $\alpha$-induced up-regulation of mir-155 inhibits adipogenesis by down-regulating early adipogenic transcription factors. Biochemical and Biophysical Research Communications 2011, 414, 618-624.

66. Sun, L.; Xie, H.; Mori, M.A.; Alexander, R.; Yuan, B.; Hattangadi, S.M.; Liu, Q.; Kahn, C.R.; Lodish, H.F. Mir193b-365 is essential for brown fat differentiation. Nature cell biology 2011, 13, 958-965.

67. Pan, S.; Zheng, Y.; Zhao, R.; Yang, X. Microrna-130b and microrna-374b mediate the effect of maternal dietary protein on offspring lipid metabolism in meishan pigs. The British journal of nutrition 2013, 109, 1731-1738.

68. Xiao, C.; Srinivasan, L.; Calado, D.P.; Patterson, H.C.; Zhang, B.; Wang, J.; Henderson, J.M.; Kutok, J.L.; Rajewsky, K. Lymphoproliferative disease and autoimmunity in mice with increased mir-17-92 expression in lymphocytes. Nature immunology 2008, 9, 405-414.

69. Ventura, A.; Young, A.G.; Winslow, M.M.; Lintault, L.; Meissner, A.; Erkeland, S.J.; Newman, J.; Bronson, R.T.; Crowley, D.; Stone, J.R., et al. Targeted deletion reveals essential and overlapping functions of the mir-17 through 92 family of mirna clusters. Cell 2008, 132, 875-886.

70. Uchida, N. Microrna-9 controls a migratory mechanism in human neural progenitor cells. Cell Stem Cell 2010, 6, 294-296.

71. Hebert, S.S.; Horre, K.; Nicolai, L.; Bergmans, B.; Papadopoulou, A.S.; Delacourte, A.; De Strooper, B. Microrna regulation of alzheimer's amyloid precursor protein expression. Neurobiology of disease 2009, 33, 422-428.

72. Park, S.Y.; Lee, J.H.; Ha, M.; Nam, J.W.; Kim, V.N. Mir-29 mirnas activate p53 by targeting p85 alpha and cdc42. Nat Struct Mol Biol 2009, 16, 23-29.

73. Koturbash, I.; Zemp, F.; Kolb, B.; Kovalchuk, O. Sex-specific radiation-induced micrornaome responses in the hippocampus, cerebellum and frontal cortex in a mouse model. Mutation research 2011, 722, 114-118.

74. Xie, S.S.; Li, X.Y.; Liu, T.; Cao, J.H.; Zhong, Q.; Zhao, S.H. Discovery of porcine micrornas in multiple tissues by a solexa deep sequencing approach. PLoS One 2011, 6, e16235.

75. Gatfield, D.; Le Martelot, G.; Vejnar, C.E.; Gerlach, D.; Schaad, O.; Fleury-Olela, F.; Ruskeepaa, A.L.; Oresic, M.; Esau, C.C.; Zdobnov, E.M., et al. Integration of 
microrna mir-122 in hepatic circadian gene expression. Genes Dev 2009, 23, 1313-1326.

76. Esau, C.; Davis, S.; Murray, S.F.; Yu, X.X.; Pandey, S.K.; Pear, M.; Watts, L.; Booten, S.L.; Graham, M.; McKay, R., et al. Mir-122 regulation of lipid metabolism revealed by in vivo antisense targeting. Cell metabolism 2006, 3, 87-98.

77. Li, A.; Song, T.; Wang, F.; Liu, D.; Fan, Z.; Zhang, C.; He, J.; Wang, S. Micrornaome and expression profile of developing tooth germ in miniature pigs. PLoS One 2012, 7, e52256.

78. Sehic, A.; Risnes, S.; Khuu, C.; Khan, Q.-E.S.; Osmundsen, H. Effects of in vivo transfection with anti-mir-214 on gene expression in murine molar tooth germ. Physiological Genomics 2011, 43, 488-498.

79. Williams, W.W.; Taheri, D.; Tolkoff-Rubin, N.; Colvin, R.B. Clinical role of the renal transplant biopsy. Nature reviews. Nephrology 2012, 8, 110-121.

80. Kozakowski, N.; Regele, H. Biopsy diagnostics in renal allograft rejection: From histomorphology to biological function. Transplant international : official journal of the European Society for Organ Transplantation 2009, 22, 945-953.

81. Mas, V.R.; Dumur, C.I.; Scian, M.J.; Gehrau, R.C.; Maluf, D.G. Micrornas as biomarkers in solid organ transplantation. American Journal of Transplantation Official Journal of the American Society of Transplantation \& the American Society of Transplant Surgeons 2013, 13, 11-19.

82. Maluf, D.G.; Dumur, C.I.; Suh, J.L.; Scian, M.J.; King, A.L.; Cathro, H.; Lee, J.K.; Gehrau, R.C.; Brayman, K.L.; Gallon, L., et al. The urine microrna profile may help monitor post-transplant renal graft function. Kidney international 2014, 85, 439-449.

83. Bhatt, K.; Mi, Q.S.; Dong, Z. Micrornas in kidneys: Biogenesis, regulation, and pathophysiological roles. American journal of physiology. Renal physiology 2011, 300, F602-610.

84. Chen, X.; Ba, Y.; Ma, L.; Cai, X.; Yin, Y.; Wang, K.; Guo, J.; Zhang, Y.; Chen, J.; Guo, X., et al. Characterization of micrornas in serum: A novel class of biomarkers for diagnosis of cancer and other diseases. Cell Res 2008, 18, 997-1006.

85. Godwin, J.G.; Ge, X.; Stephan, K.; Jurisch, A.; Tullius, S.G.; Iacomini, J. Identification of a microrna signature of renal ischemia reperfusion injury. Proceedings of the National Academy of Sciences of the United States of America 2010, 107, 14339-14344.

86. Kanak, M.A.; Takita, M.; Shahbazov, R.; Lawrence, M.C.; Chung, W.Y.; Dennison, A.R.; Levy, M.F.; Naziruddin, B. Evaluation of microrna375 as a novel biomarker for graft damage in clinical islet transplantation. Transplantation 2015, 99, 1568-1573.

87. Chawla, J.P.S.; Nageshwar, I.; Kanwaldeep Singh, S.; Atul, S.; Sunpreet Kaur, K.; Pratiksha, P. Role of mirna in cancer diagnosis, prognosis, therapy and regulation of its expression by epstein-barr virus and human papillomaviruses: With special reference to oral cancer. Oral Oncology 2015, 51, 731-737.

88. Sun, L.; Chen, Y.; Su, Q.; Tang, X.; Liang, Y.; Che, G.; Luo, F. Increased plasma mirna-30a as a biomarker for non-small cell lung cancer. Medical Science Monitor International Medical Journal of Experimental \& Clinical Research 2016, 22, 
647-655.

89. Wang, J.; Ye, H.; Zhang, D.; Hu, Y.; Yu, X.; Long, W.; Zuo, C.; Yu, Y.; Xu, G.; Liu, S. Microrna-410-5p as a potential serum biomarker for the diagnosis of prostate cancer. Cancer Cell International 2016, 16, 1-6.

90. Guo, S.; Guo, W.; Li, S.; Dai, W.; Zhang, N.; Zhao, T.; Wang, H.; Ma, J.; Yi, X.; Ge, R. Serum mir-16: A potential biomarker for predicting melanoma prognosis. Journal of Investigative Dermatology 2016.

91. Widodo; Djati, M.S.; Rifa'i, M. Role of micrornas in carcinogenesis that potential for biomarker of endometrial cancer. Annals of Medicine and Surgery 2016, 7, 9-13.

92. Shapiro, M.D.; Bagley, J.; Latz, J.; Godwin, J.G.; Ge, X.; Tullius, S.G.; Iacomini, J. Microrna expression data reveals a signature of kidney damage following ischemia reperfusion injury. PLoS One 2011, 6, e23011.

93. Shan, J.; Feng, L.; Luo, L.; Wu, W.; Li, C.; Li, S.; Li, Y. Micrornas: Potential biomarker in organ transplantation. Transplant immunology 2011, 24, 210-215.

94. Anglicheau, D.; Sharma, V.K.; Ding, R.; Hummel, A.; Snopkowski, C.; Dadhania, D.; Seshan, S.V.; Suthanthiran, M. Microrna expression profiles predictive of human renal allograft status. Proceedings of the National Academy of Sciences of the United States of America 2009, 106, 5330-5335.

95. Tao, J.; Yang, X.; Han, Z.; Lu, P.; Wang, J.; Liu, X.; Wu, B.; Wang, Z.; Huang, Z.; $\mathrm{Lu}, \mathrm{Q}$, et al. Serum microrna-99a helps detect acute rejection in renal transplantation. Transplantation proceedings 2015, 47, 1683-1687.

96. Wu, C.I.; Li, W.H. Evidence for higher rates of nucleotide substitution in rodents than in man. Proceedings of the National Academy of Sciences of the United States of America 1985, 82, 1741-1745.

97. Rocha, D.; Plastow, G. Commercial pigs: An untapped resource for human obesity research? Drug Discov Today 2006, 11, 475-477.

98. Cooper, D.K.; Gollackner, B.; Sachs, D.H. Will the pig solve the transplantation backlog? Annu Rev Med 2002, 53, 133-147.

99. Leung, A.K.; Sharp, P.A. Micrornas: A safeguard against turmoil? Cell 2007, 130, 581-585.

100. Martini, P.; Sales, G.; Calura, E.; Brugiolo, M.; Lanfranchi, G.; Romualdi, C.; Cagnin, S. Systems biology approach to the dissection of the complexity of regulatory networks in the s. Scrofa cardiocirculatory system. International journal of molecular sciences 2013, 14, 23160-23187.

101. Chen, C.; Ai, H.; Ren, J.; Li, W.; Li, P.; Qiao, R.; Ouyang, J.; Yang, M.; Ma, J.; Huang, L. A global view of porcine transcriptome in three tissues from a full-sib pair with extreme phenotypes in growth and fat deposition by paired-end rna sequencing. BMC Genomics 2011, 12, 448.

102. Zhao, W.; Liu, W.; Tian, D.; Tang, B.; Wang, Y.; Yu, C.; Li, R.; Ling, Y.; Wu, J.; Song, S., et al. Waprna: A web-based application for the processing of rna sequences. Bioinformatics 2011, 27, 3076-3077. 